\title{
Functional roles of DExD/H-box RNA helicases in Pre-mRNA splicing
}

\author{
Yen-Chi Liu and Soo-Chen Cheng
}

\begin{abstract}
Splicing of precursor mRNA takes place via two consecutive steps of transesterification catalyzed by a large ribonucleoprotein complex called the spliceosome. The spliceosome is assembled through ordered binding to the pre-mRNA of five small nuclear RNAs and numerous protein factors, and is disassembled after completion of the reaction to recycle all components. Throughout the splicing cycle, the spliceosome changes its structure, rearranging RNA-RNA, RNA-protein and protein-protein interactions, for positioning and repositioning of splice sites. DExD/H-box RNA helicases play important roles in mediating structural changes of the spliceosome by unwinding of RNA duplexes or disrupting RNA-protein interactions. DExD/H-box proteins are also implicated in the fidelity control of the splicing process at various steps. This review summarizes the functional roles of DExD/H-box proteins in pre-mRNA splicing according to studies conducted mostly in yeast and will discuss the concept of the complicated splicing reaction based on recent findings.
\end{abstract}

Keywords: DExD/H-box RNA helicase, Splicing, Spliceosome, RNA processing

\section{Introduction}

RNA splicing is a fundamental process in eukaryotic gene expression and is also highly regulated in higher eukaryotic cells. Many human diseases are associated with splicing defects or are caused by splicing misregulation $[1,2]$. The splicing reaction requires five small nuclear RNAs (snRNAs), U1, U2, U4, U5 and U6, and a large number of proteins [3-5]. These factors assemble on the pre-mRNA to form a large ribonucleoprotein complex, called the spliceosome, on which the catalytic reactions take place.

The splicing cycle can be divided into four phases: spliceosome assembly, spliceosome activation, catalytic reactions, and spliceosome disassembly. Spliceosome assembly involves sequential binding of the five snRNAs, in the form of small nuclear ribonucleoprotein particles (snRNPs), to the pre-mRNA. The snRNAs play roles in the recognition and alignment of splice sites. Upon the binding of all five snRNAs, the spliceosome undergoes a major structural rearrangement, releasing $\mathrm{U} 1$ and $\mathrm{U} 4$, to form the active spliceosome, which can then catalyze two steps of the transesterification reaction, generating

\footnotetext{
* Correspondence: mbscc@ccvax.sinica.edu.tw

Institute of Molecular Biology, Academia Sinica, Taipei, Taiwan 115, Republic
} of China

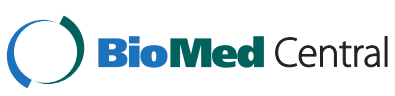

(c) 2015 Liu and Cheng. This is an Open Access article distributed under the terms of the Creative Commons Attribution License (http://creativecommons.org/licenses/by/4.0), which permits unrestricted use, distribution, and reproduction in any medium, provided the original work is properly credited. The Creative Commons Public Domain Dedication waiver (http:// creativecommons.org/publicdomain/zero/1.0/) applies to the data made available in this article, unless otherwise stated. lariat intermediates and products. After the reaction, the spliceosome first releases the mature message and then is disassembled so that the splicing factors can be recycled [6, 7].

The structures of the catalytic core of the spliceosome and self-splicing group II introns are highly similar. They also share the same chemical mechanism and are believed to be evolutionarily related. For these reasons, pre-mRNA splicing is thought to also be an RNA-based reaction, with protein factors to support and modulate the structure of RNA in the catalytic core. Accumulating evidence supports RNA-catalyzed splicing of spliceosomal introns [8-12]. The structures of group II introns have recently been solved [13-15]. Several structures from different catalytic states have been determined and have provided structural and mechanistic insights into how the introns switch conformations between steps to position the splice sites [16].

Structural changes of the spliceosome are mediated by DExD/H-box RNA helicases [17-19]. DExD/H-box proteins are a family of RNA-dependent ATPases (or NTPases), which utilize the energy from ATP hydrolysis to modulate the structure of RNA or ribonucleoprotein complexes $[20,21]$. Eight $\mathrm{DExD} / \mathrm{H}$-box proteins are required for the splicing reaction, two for each phase of 
the spliceosome pathway [22, 23]. Prp5 and Sub2 are required for the assembly phase of the spliceosome, with both involved in the formation of the prespliceosome [24-26]. Prp28 and Brr2 are required for activation of the spliceosome in releasing of $\mathrm{U} 1$ and $\mathrm{U} 4$, respectively [27-29]. Prp2 and Prp16 are required for each of the catalytic steps, and Prp22 and Prp43 are required for disassembly of the spliceosome [30-35]. Besides their ATPase-associated functions, Prp2, Prp5, Prp16 and Prp22 have been shown to have an ATP-independent function in the splicing pathway [25, 36-38]. Prp5, Prp16, Prp22 and Prp28 have also been demonstrated to play roles in the control of splicing fidelity [37, 39-44]. In this review, we summarize the functional roles of these proteins in the spliceosome pathway and discuss the underlying mechanisms of their functions.

\section{Review}

\section{Overview of pre-mRNA splicing pathway}

The spliceosome is assembled in a stepwise manner through ordered binding of the five snRNAs and protein factors to the pre-mRNA [6, 7]. U1 recognizes the $5^{\prime}$ splice site through RNA base pairing with the $5^{\prime}$ splice site sequence, and binds to the pre-mRNA to form the commitment complex (CC), which can be resolved into two complexes, $\mathrm{CC} 1$ and $\mathrm{CC} 2$, by gel electrophoresis. Formation of the commitment complex does not require ATP [45]. U2 binds to the branch site sequence, also through RNA base pairing, to form the prespliceosome. Although U1 normally binds to the pre-mRNA prior to $\mathrm{U} 2$ binding, $\mathrm{U} 2$ can bind to the branch site independent of U1 binding in mammalian extracts [46]. After binding of U1 and U2 snRNPs, U4, U5 and U6 are recruited to the spliceosome as a pre-formed U4/U6.U5 tri-snRNP. Neither U4/U6 di-snRNP or U5 snRNP alone binds to the spliceosome [47].

Loading of the tri-snRNP marks the end of the assembly phase of the spliceosome. The spliceosome then undergoes a dramatic structural rearrangement, releasing $\mathrm{U} 1$ and $\mathrm{U} 4$, and forming new base pairs between $\mathrm{U} 2$ and $\mathrm{U} 6$ and between $\mathrm{U} 6$ and the $5^{\prime}$ splice site $[6,7]$. RNA-RNA base pairings form the framework of the catalytic core of the spliceosome, which is highly similar to that of self-splicing group II introns $[48,49]$. The structure is presumably stabilized and modulated by protein factors. A protein complex associated with Prp19, named NTC for NineTeen Complex[50], is required for stable association of U5 and U6 with the spliceosome after the release of $\mathrm{U} 1$ and $\mathrm{U} 4$ to direct specific interactions of U5 and U6 with pre-mRNA [50-52]. Other proteins may be also involved in finetuning the RNA structure during the splicing reaction.

The catalytic reaction comprises two consecutive steps of transesterification. Each of the catalytic steps involves an ATP-dependent step, which requires a DExD/H-box protein, and an ATP-independent step, which requires a specific set of proteins to promote the catalytic reaction. Exchange of proteins modulates structural changes of the spliceosome during the catalytic reaction. After completion of the reaction, the spliceosome first releases the mRNA and is then disassembled to recycle all components. Both steps require ATP and DExD/H-box proteins $[6,7,53]$.

\section{$\mathrm{DExD} / \mathrm{H}$-box proteins in the splicing reaction}

Eight DExD/H-box proteins are involved in the splicing reaction, two for each phase of the pathway [22, 23]. In general they function as RNA chaperones to modulate the structure of RNA molecules or ribonucleoprotein complexes. Except for Brr2, which is an intrinsic component of U5 snRNP, all splicing DExD/H-box proteins only transiently interact with the spliceosome during the splicing reactions. Prp5, Sub2 and Prp28 belong to the DEAD-box family, and Brr2 belongs to the Ski2-like family. Both families of proteins exclusively use ATP for their functions. The four proteins involved in the catalytic step or disassembly, Prp2, Prp16, Prp22 and Prp43, belong to the DEAH/RHA family, and can use all four kinds of nucleotide triphosphates as energy sources [17-19]. These four proteins have been demonstrated to bind to the spliceosome in an ATP-independent manner, and are dissociated upon hydrolysis of ATP. They are retained on the spliceosome only when ATP is absent or the ATPase function of the protein is compromised. Mutations that abolish the ATPase activity frequently exhibit dominant-negative phenotypes. The functional roles of these proteins are illustrated in Fig. 1.

\section{Prp5 and Sub2 in spliceosome assembly}

During early stage of spliceosome assembly, the branch binding protein BBP (branchpoint-binding protein; SF1 in human and Msl5 in yeast) binds to the branch site first and bridge the $5^{\prime}$ splice site and $3^{\prime}$ splice site by interacting with U1 snRNP proteins Prp40 and Mud2 (U2AF65 in human) [54-56], which bind pre-mRNA in the $3^{\prime}$ splice site region $[54,55,57]$. BBP and Mud2, forming a heterodimer, are thought to recruit Sub2 to or near the branch site region to mediate the release of Msl5 and Mud2 and to allow U2 snRNP binding to the branch site $[58,59]$. Although Sub2 is essential for yeast under normal growth conditions, deletion of MUD2 can bypass the requirement of SUB2, suggesting that an essential function of Sub2 is the removal of Mud2 to facilitate the association of U2 snRNP with the spliceosome [26]. It has also been shown that formation of CC2, but not CC1, requires Sub2 [60], indicative of an additional function of Sub2 in formation of the commitment complex. Besides functional roles in pre-mRNA 
Lu and Chen Journal of Biomedical Science (2015) 22:54

Page 3 of 9

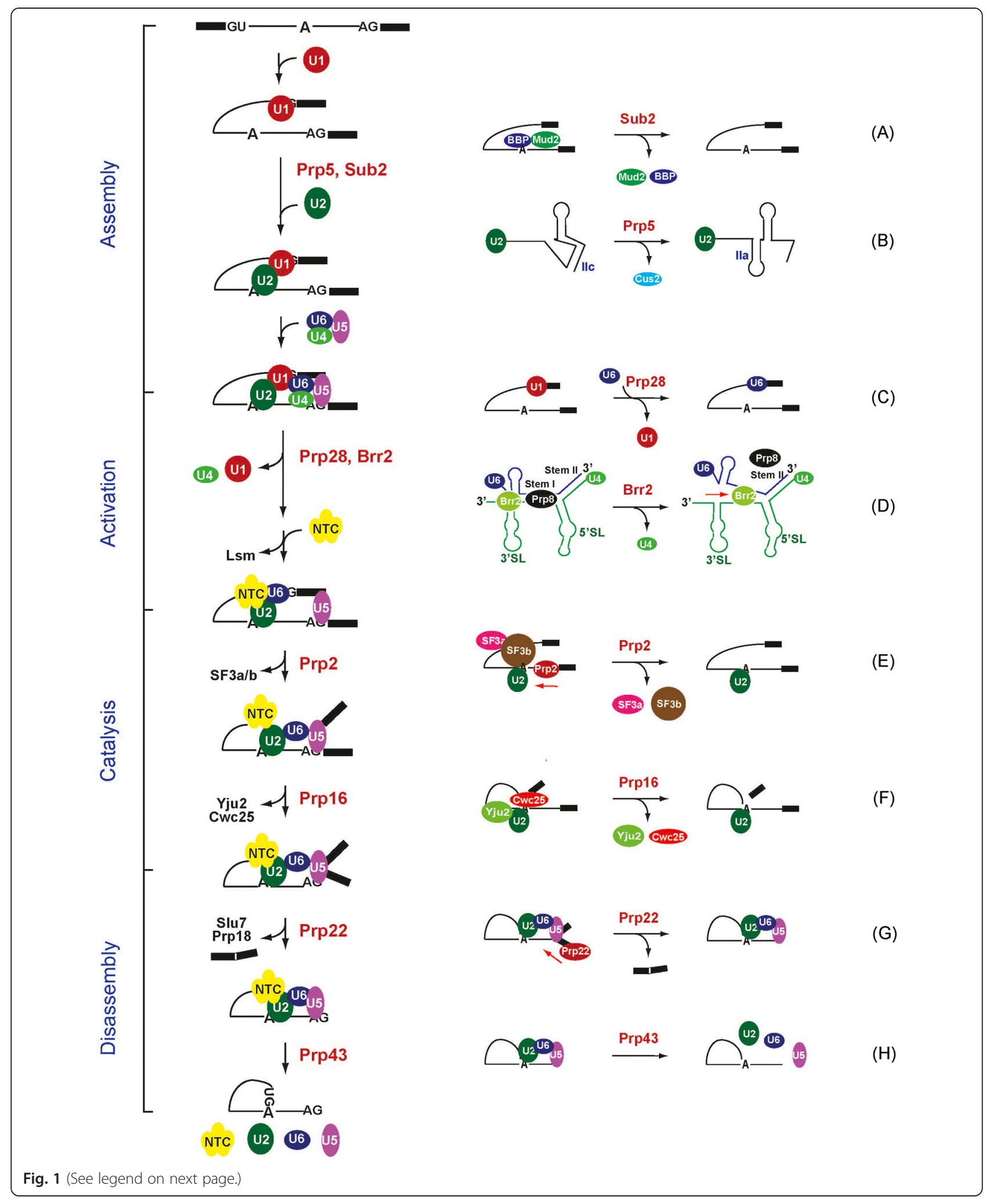


(See figure on previous page.)

Fig. 1 Schematic representation of the spliceosome pathway and the function of the DExD/H-box proteins involved. The spliceosome pathway can be divided into four phases: spliceosome assembly, spliceosome activation, catalytic steps and spliceosome disassembly. Two DExD/H-box proteins are required for each phase of the pathway, and their functions are shown. a Sub2 is implicated in the removal of BBP/Mud2 from binding to the branch site. $\mathbf{b}$ Prp5 is implicated in the removal of Cus2 from U2 snRNP and converts U2 snRNA into a functional form. $\mathbf{c}$ Prp28 is implicated in the removal of U1C or destabilization of U1 snRNA from the $5^{\prime}$ splice site to promote U1/U6 switch at the $5^{\prime}$ splice site. $\mathbf{d}$ Brr2 catalyzes U4/U6 unwinding to release U4. e Prp2 is required for remodeling of the spliceosome structure by destabilization of SF3a/b. Prp2 binds to the pre-mRNA in a region downstream of the branch site and translocates in a $3^{\prime}$-to' $5^{\prime}$ direction to destabilize SF3a/b. $\mathbf{f}$ Prp16 is required for the release of Yju2/Cwc25. g Prp22 mediates the release mature mRNA, and $\mathbf{h}$ Prp43 mediates spliceosome disassembly. Prp22 binds to the mature mRNA in a region downstream of the splice junction and translocates in a 3'-to'5' direction to destabilize mRNA from the spliceosome

splicing, Sub2 has also been reported to be involved in mRNA export [61-63].

Formation of the prespliceosome requires DExD/Hbox protein Prp5. Prp5 has been shown to mediate the conformational change of U2 snRNP by hydrolysis of ATP, and its ATPase activity is stimulated to a much higher level by U2 snRNA than by other snRNAs or nonspecific RNAs [64]. Several U2 snRNP components, including Prp9, Prp11, Prp21, Cus1, Cus2 and stem IIa of U2 snRNA, genetically interact with Prp5 [65-68], thus functionally linking Prp5 and U2 snRNP. In the absence of Cus2, the formation of prespliceosome requires Prp5, but the ATPase function of Prp5 is dispensable for cellular growth and splicing [25]. Prp5 was thus proposed to promote the formation of stem IIa by displacing Cus2 from U2 in an ATPdependent manner to form a functional U2 snRNP that associates with the spliceosome, and Prp5 has an additional ATP-independent function in prespliceosome formation $[24,25]$. Recently, Prp5 was shown to bind directly to U2 snRNA on binding to the spliceosome [40]. Prp5 is retained on the spliceosome when pre-mRNA carries mutations in the branch site, and only upon its release can tri-snRNP be recruited to the spliceosome [40].

In the fission yeast Schizosaccharomyces pombe and in human, Prp5 was shown to associate with U1 snRNPs and U2 snRNPs via its N-terminal domain, bridging U1 and U2 snRNPs to form the prespliceosome [68]. Due to the lack of the corresponding N-terminal U1-interacting domain, the bridging function of U1 and U2 snRNPs by Prp5 is not found in Saccharomyces cerevisiae [68].

Prp5 was previously proposed to play a role in splicing fidelity control to proofread the branch site by competing with base pairing between U2 snRNA and the branch site sequence in an ATP-dependent manner $[39,40]$. A recent report reveals an alternative mechanism for Prp5 functions in proofreading the branch site sequence by counteracting tri-snRNP binding independent of ATP [40]. More details are discussed in a later section.

\section{Prp28 and Brr2 in spliceosome activation}

Two DExD/H-box proteins, Prp28 and Brr2, are involved in spliceosome activation. Prp28 was implicated in the displacement of $\mathrm{U} 1$ in promoting U1/U6 switch at the $5^{\prime}$ splice site [29]. The requirement of Prp28 can be bypassed by mutations in U1 snRNP components, U1C (Yhc1 in yeast), Prp42, cap-binding protein $\mathrm{Cbp80}$, and Ynl187, some of which are known to stabilize U1-5' splice site interactions. This suggests that Prp28 may destabilize U1-5' splice site interactions by destabilization of proteins binding to U1 snRNA or to the $5^{\prime}$ splice site $[69,70]$.

The human Prp28 ortholog (hPrp28, also known as DDX23) has an extra N-terminal domain with RS repeats that are phosphorylated by SRPK2 (serine/arginine protein-specific kinase 2). hPrp28 has been shown to associate with the tri-snRNP, and phosphorylation of Prp28 plays a role in regulating the recruitment of the tri-snRNP to the spliceosome [71]. Prp28 has also been demonstrated to proofread the $5^{\prime}$ splice site during spliceosome assembly [42] (see below).

Brr2 is an intrinsic component of U5 snRNP and is associated with the spliceosome through the binding of tri-snRNP. Brr2 is required for spliceosome activation by mediating the release of $\mathrm{U} 4[27,28]$. Brr2 has been demonstrated to unwind RNA duplexes in vitro [27, 28], and unwinding of the U4/U6 duplex can also occur on the purified snRNP [27], implicating Brr2 in mediating U4/U6 unwinding during spliceosome activation [27, 28, $72,73]$. Brr2 has been shown to load onto the single stranded region of $\mathrm{U} 4$ located downstream of U4/U6 stem I, and then to translocate along U4 in the $3{ }^{\prime}$-to-5' direction to disrupt stem I on separating U4/U6 duplex $[74,75]$. Prp8 plays a central role in regulating the function of Brr2 on the spliceosome. The Jab/MPN domain in the C-terminal region of $\operatorname{Prp} 8$ has been shown to stimulate the unwinding activity of Brr2 [73], but the very C-terminal tail of $\operatorname{Prp} 8$ inhibits the RNA-binding, ATPase and U4/U6 unwinding activities of Brr2 [76]. The RNase $\mathrm{H}$ domain of $\operatorname{Prp} 8$ can also bind the same region of $\mathrm{U} 4$ where Brr2 binds, thus preventing the binding of Brr2 and inhibiting U4/U6 unwinding [74]. 
Brr2 is unusual among DExD/H-box proteins in that it contains two helicase domains [77]. The N-terminal helicase domain functions in unwinding activity [72], but the $\mathrm{C}$-terminal helicase domain is catalytically inactive. Besides its role in mediating U4/U6 unwinding during spliceosome activation, Brr2 has additional roles in regulating the function of other splicing factors. The C-terminal domain of Brr2 interacts with many spliceosomal components, serving as protein-protein interaction platform [78, 79]. These proteins include Prp2, Prp16 and Slu7, which are involved in catalytic steps, and Ntr2, which is required for spliceosome disassembly $[78,80,81]$. It is possible that Brr2 serves as the platform for the recruitment of these splicing factors to the spliceosome at various stages of post-activated spliceosomes. Consistent with this notion, Prp16 and Slu7 have been shown to compete with the binding of Ntr2 to the spliceosome to prevent premature disassembly of the spliceosome [82]. The C-terminal Sec63-2 domain of Brr2 has been shown to interfere with RNA binding of Prp16, thereby modulating the ATPase activity of Prp16 [83]. Brr2 has also been implicated in the mediation of spliceosome disassembly [84], but whether its ATPase activity is involved remains controversial [85].

\section{Prp2, Prp16 and Prp22 in the catalytic step}

The first catalytic reaction requires $\mathrm{DExD} / \mathrm{H}$-box protein Prp2 to remodel the spliceosome [31, 36, 86]. For its function, Prp2 requires the cofactor Spp2, which was initially identified as a multi-copy suppressor of the temperature-sensitive prp2-1 mutant and shown to interact with Prp2 through its G-patch domain [87, 88]. Like Prp2, Spp2 can associate with the spliceosome prior to the first catalytic reaction and is released along with Prp2 upon ATP hydrolysis [87]. Although Spp2 was previously shown to be required for the recruitment of Prp2 to the spliceosome, a recent study using a purified splicing system revealed that Spp2 is dispensable for Prp2 recruitment, but functions in coupling the ATPase activity of Prp2 to remodeling of the spliceosome into a catalytically active form [89].

The function of Prp2 has recently been demonstrated to associate with destabilization of U2 snRNP components SF3a/b complexes from the spliceosome $[36,86]$. SF3b component SAP155 and its Saccharomyces cerevisiae ortholog Hsh155 have been shown to crosslink to intron sequences flanking the branch site, suggesting a role of SF3b in stabilizing U2-branch site interaction during spliceosome formation $[90,91]$. Conceivably, destabilization of SF3a/b allows exposure of the branchpoint and also relieves the rigidity of the catalytic center of the spliceosome so that RNA elements can interact to initiate the catalytic reaction. The function of $\operatorname{Prp} 2$ in the first catalytic step also requires an eIF4G-like protein,
Cwc22 [92]. Cwc22 is not required for the recruitment of Prp2 to the spliceosome, but in its absence, Prp2 is dissociated from the spliceosome upon ATP hydrolysis without productive action [92].

Studies from proteomic and dual-color fluorescence cross-correlation spectroscopic (dcFCCS) analysis revealed that several other proteins, including Cwc24, Cwc27 and Bud13, are displaced during Prp2-mediated remodeling of the spliceosome, but the functions of these proteins are not known [93]. After the action of Prp2, high-affinity binding sites are created for Yju2 and Cwc25, which stabilize first-step conformation of the catalytic center of the spliceosome to promote the first reaction [93]. Prp2 has also been implicated in mediating an ATP-independent conformational change of the spliceosome, but the mechanism is unknown [36].

Prp2 has been shown to interact with the C-terminal region of Brr2 [81] and with pre-mRNA by UV-crosslinking analysis $[81,94]$. A region of the intron sequence 23 to 33 nucleotides downstream of the branchpoint was shown to be necessary and sufficient for the ATP-dependent function of Prp2. It has been suggested that Prp2 is recruited to the spliceosome through interaction with Brr2 and then translocated to the pre-mRNA, which stimulates its ATPase activity. Hydrolysis of ATP powers Prp2 to move on the pre-mRNA in the $3^{\prime}$-to- $5^{\prime}$ direction to destabilize SF3a/b [81].

The second catalytic reaction requires the $\mathrm{DExD} / \mathrm{H}$ box protein Prp16 and three other proteins, Slu7, Prp18 and Prp22 [38, 95, 96], although Prp22 was shown to be not required in a recent study using a purified splicing system [97]. Prp16 was originally identified as a suppressor of branchpoint A-to-C (or brC) mutant of the actin intron $[98,99]$, but was found to be only required for the second catalytic reaction in vitro [32]. Prp16 was proposed to induce a conformational change in the spliceosome prior to the second catalytic reaction, judging from the protection of the 3' splice site from RNase $\mathrm{H}$ cleavage upon Prp16 action [100]. Although UVcrosslinking analysis revealed protection of the 3 ' splice site may be due to Prp22 binding [101], other changes in the RNA structure of the spliceosome have also been observed. Genetic data have suggested that the U2 helix II switches from IIa to IIc conformation, and U2/U6 helix I is destabilized during the transition from the first to second catalytic step [102-104]. Since Prp16 can catalyze unwinding of synthetic RNA duplexes in vitro [105], it was proposed that $\operatorname{Prp} 16$ may mediate unwinding of the RNA duplex during the transition $[102,106]$. However, it is also possible that change of the RNA structure is a consequence of protein displacement mediated by Prp16.

Recent studies have demonstrated dual roles of Prp16 in the catalytic step. After the first reaction, Prp16 is 
required for the displacement of Yju2 and Cwc25, which become tightly associated with the spliceosome [37]. This function in remodeling of the spliceosome requires ATP hydrolysis and results in stable association of Slu7/ Prp18 to promote the second reaction [97]. As in the first step, the RNA structure in the catalytic center of the spliceosome is less rigid upon displacement of Yju2 and Cwc25. This allows positioning of the 3' splice site to the catalytic center. PRP16 has also been demonstrated genetic interactions with ISY1, PRP8 and U6 snRNA, suggesting that they are potential targets of Prp16 [107-109]. Whether these factors interact with Prp16 directly or through interaction with Cwc25 remains unknown. Prp16 also has an ATP-independent function in the first catalytic step in promoting the binding of Cwc25 to impaired spliceosomes. Cwc25 binds tightly to the first-step spliceosome, but does not bind well to the pre-catalytic spliceosome. Although Prp16 normally binds to the spliceosome after the first reaction, under conditions that the reaction is impeded such as when pre-mRNA carries mutations at the branch site, Prp16 can bind to the spliceosome to stabilize the binding of Cwc25 to promote the first reaction without needing ATP [37].

\section{Prp22 and Prp43 in spliceosome disassembly}

The primary function of $\operatorname{Prp} 22$ is to mediate the release of mature mRNA after completion of the splicing reaction [33]. Prp22 binds to the spliceosome together with Slu7 and Prp18 during the second catalytic step and was previously shown to be also required for the second reaction [38]. However, a recent study using a purified splicing system reported Prp22 is not required for the second reaction [93]. Prp22 binds directly to the intron sequence downstream of the branch site prior to the reaction [101] and translocates to the mRNA downstream of the exon-exon junction after exon ligation. It was proposed that Prp22 promotes disruption of mRNA/U5 contacts by moving along mRNA in the $3^{\prime}$-to- $5^{\prime}$ direction in releasing the mRNA from the spliceosome [110]. Prp22 has been demonstrated to unwind RNA duplexes in vitro $[38,111]$, and the helicase activity is essential for mRNA release [112], suggesting that Prp22 might mediate unwinding of mRNA/U5 base pairings. On the other hand, genetic data showed that Prp8-Arg1753 mutants suppress Prp22 helicase-defective mutants [113] as well as specific U5 loop 1 mutant alleles [114]. These results suggest that Prp8-Arg1753 may play a role in stabilizing U5/exon interactions before exon ligation, and Prp22 may function in disrupting RNA-RNA or RNA-protein interactions that are normally stabilized by Prp8.

Prp43 is the key player in mediating spliceosome disassembly [34, 35, 115]. It mediates disassembly of the spliceosome normally after completion of the splicing reaction, but can also mediate disassembly of the impaired spliceosome intermediates or spliceosomes arrested in the middle of the pathway $[82,116]$. The function of Prp43 requires two co-factors, Ntr1 (also called Spp382) and Ntr2, which form a dimeric complex for the recruitment of Prp43 to the spliceosome [35, 117, 118]. Prp43 can also associate with Ntr1-Ntr2 to form a functional NTR complex, which catalyzes disassembly of the affinity-purified spliceosome in the presence of ATP [35]. Ntr1 interacts with both Ntr2 and Prp43 on formation of the NTR complex. The G-patch domain of Ntr1 interacts with Prp43 and stimulates the helicase activity of Prp43 [119]. Ntr2 interacts with U5 component Brr2, and this interaction is proposed to mediate the recruitment of NTR to the spliceosome [80]. Prp43 has been demonstrated to unwind RNA duplexes in vitro [120], but whether Prp43 catalyzes RNA unwinding on the spliceosome to mediate disassembly is not clear. Another DExD/H-box protein Brr2 has also been implicated in the disassembly by disruption of U2/U6 base pairings [84]. However, a recent study argues against the involvement of the ATPase function of Brr2 since, while Brr2 is ATP-specific, all four nucleotide triphosphates could be used as the energy source in the disassembly assay using a purified splicing system [85].

Prp43 has been demonstrated to be functionally linked to discard of spliceosome intermediates rejected from the pathway [115]. Dissection of the pathway revealed that only specific intermediate complexes, those formed after the action of DExD/H-box proteins Prp2 and Prp16, are susceptible to Prp43-mediated disassembly, suggesting a function of $\mathrm{DExD} / \mathrm{H}$-box proteins in marking the spliceosome for susceptibility to the disassembly machinery, in accordance with their proposed roles in splicing fidelity control [82].

\section{DExD/H-box proteins in splicing fidelity control}

The first insight into the involvement of $\mathrm{DExD} / \mathrm{H}$-box proteins in splicing fidelity control came from the isolation of PRP16 mutants as suppressors to branchpoint A-to-C mutation [98, 99]. The level of suppression was found to inversely correlate with that of the ATPase activity of Prp16. A model for a role of Prp16 in splicing fidelity control by a kinetic proofreading mechanism was proposed $[44,121]$. In this model, Prp16 can direct the impaired spliceosome to a discard pathway coupling the energy from ATP hydrolysis. A conformational change in the spliceosome, affected by the sequence in the branchpoint, competes with the action of Prp16 to prevent the spliceosome from being rejected. While mutation in the branchpoint impedes the conformational change of the spliceosome, it allows Prp16 to act on and reject the impaired spliceosome. Reducing the ATPase activity of Prp16 allows more time for 
the spliceosome to proceed through the conformational change needed for progression to the normal pathway. Based on genetic data, Prp2, Prp5, Prp22 and Prp28 have been proposed to play roles in proofreading the catalytic core of the spliceosome, the branch site, 3' splice site and the $5^{\prime}$ splice, respectively, by similar mechanisms [37, 39-44, 122]. Recent biochemical analysis has revealed an ATP-independent function of Prp16 in promoting the first catalytic reaction by stabilizing the binding of Cwc25 [37]. While splicing of branchpoint-mutated pre-mRNA is completely blocked in the absence of Prp16, ATPase-deficient Prp16 allows progression of the first reaction to a large extent. Based on this finding, it was proposed that Prp16-mediated rejection of impaired spliceosomes might be a consequence of Cwc25 displacement prior to the catalytic reaction, rendering the spliceosome susceptible to NTR for disassembly. The relative ratio of the ATPindependent to ATP-dependent function of Prp16 determines the efficiency of splicing proceeding through the first reaction $[37,123]$. In this regard, Prp16 may only play a passive role in proofreading the branch site sequence. This also raises a question of whether all splicing $\mathrm{DExD} / \mathrm{H}$-box proteins share a common feature of controlling splicing fidelity by the ATP-dependent proofreading mechanism. At least for Prp5, an alternative ATP-independent mechanism explaining the suppression effect of branch site mutants by $\operatorname{Prp} 5$ was recently proposed [40].

\section{Conclusions}

Originating from self-splicing group II introns, the spliceosome has evolved into a highly sophisticated structure that requires eight $\mathrm{DExD} / \mathrm{H}$-box proteins to mediate its structural rearrangements along the splicing pathway. These proteins play roles in remodeling of the spliceosome by either unwinding of RNA duplexes or disrupting RNA-protein interactions to facilitate structural changes of the spliceosome. Under conditions that structural changes can be more easily achieved, the function of $\mathrm{DExD} / \mathrm{H}$-box proteins can be dispensable. Although several DExD/H-box proteins have been demonstrated to play roles in proofreading splice sites based on genetic data, studies using biochemical approaches have shed more insights into the functional roles of these proteins, and provided new explanations for previous genetic data by alternative mechanisms. It is necessary to analyze the function of these proteins in more details to elucidate the mechanism of splicing fidelity control.

\section{Competing interests}

The authors declare that they have no competing interests.

Authors' contributions

YCL and SCC wrote the manuscript together and approved the manuscript.

\section{Acknowledgments}

We thank A. Peña for English editing. This work was supported by a grant from the Academia Sinica and Minister of Science and Technology (Taiwan), MoST103-2432-B-001-056.

Received: 18 May 2015 Accepted: 29 June 2015

Published online: 16 July 2015

\section{References}

1. Padgett RA. New connections between splicing and human disease. Trends Genet. 2012;28:147-54

2. Singh RK, Cooper TA. Pre-mRNA splicing in disease and therapeutics. Trends Mol Med. 2012;18:472-82.

3. Brody E, Abelson J. The "spliceosome": yeast pre-messenger RNA associates with a 405 complex in a splicing-dependent reaction. Science. 1985;228:963-7.

4. Frendewey $D$, Keller W. Stepwise assembly of a pre-mRNA splicing complex requires U-snRNPs and specific intron sequences. Cell. 1985;42:355-67.

5. Grabowski PJ, Seiler SR, Sharp PA. A multicomponent complex is involved in the splicing of messenger RNA precursors. Cell. 1985;42:345-53.

6. Wahl MC, Will CL, Lührmann R. The spliceosome: design principles of a dynamic RNP machine. Cell. 2009;136:701-18.

7. Brow DA. Allosteric cascade of spliceosome activation. Annu Rev Genet. 2002;36:333-60.

8. Valadkhan S. snRNAs as the catalysts of pre-mRNA splicing. Curr Opin Chem Biol. 2005;9:603-8.

9. Madhani HD, Guthrie C. A novel base-pairing interaction between U2 and U6 snRNAs suggests a mechanism for the catalytic activation of the spliceosome. Cell. 1992;71:803-17.

10. Sun JS, Manley JL. A novel U2-U6 snRNA structure is necessary for mammalian mRNA splicing. Genes Dev. 1995;9:843-54.

11. Burke JE, Sashital DG, Zuo X, Wang YX, Butcher SE. Structure of the yeast U2/U6 snRNA complex. RNA. 2012;18:673-83.

12. Fica SM, Tuttle N, Novak T, Li NS, Lu J, Koodathingal P, et al. RNA catalyses nuclear pre-mRNA splicing. Nature. 2013;503:229-34.

13. Toor N, Keating KS, Taylor SD, Pyle AM. Crystal structure of a self-spliced group II intron. Science. 2008;320:77-82.

14. Chan RT, Robart AR, Rajashankar KR, Pyle AM, Toor N. Crystal structure of a group II intron in the pre-catalytic state. Nat Struct Mol Biol. 2012;19:555-7.

15. Robart AR, Chan RT, Peters JK, Rajashankar KR, Toor N. Crystal structure of a eukaryotic group II intron lariat. Nature. 2014;514:193-7.

16. Marcia M, Somarowthu S, Pyle AM. Now on display: a gallery of group II intron structures at different stages of catalysis. Mob DNA. 2013:4:14.

17. Jarmoskaite I, Russell R. RNA helicase proteins as chaperones and remodelers. Annu Rev Biochem. 2014;83:697-725.

18. Jankowsky E. RNA helicases at work: binding and rearranging. Trends Biochem Sci. 2011;36:19-29.

19. Pyle AM. Translocation and unwinding mechanisms of RNA and DNA helicases. Annu Rev Biophys. 2008:37:317-36.

20. Schwer B. A new twist on RNA helicases: DExH/D box proteins as RNPases. Nat Struct Biol. 2001;8:113-6.

21. Will CL, Luhrmann R. Molecular biology. RNP remodeling with DExH/D boxes. Science. 2001;291:1916-7.

22. Wassarman DA, Steitz JA. RNA splicing. Alive with DEAD proteins. Nature. 1991;349:463-4.

23. Staley JP, Guthrie C. Mechanical devices of the spliceosome: motors, clocks, springs, and things. Cell. 1998;92:315-26.

24. Perriman R, Ares Jr M. ATP can be dispensable for prespliceosome formation in yeast. Genes Dev. 2000;14:97-107.

25. Perriman R, Barta I, Voeltz GK, Abelson J, Ares Jr M. ATP requirement for Prp5p function is determined by Cus2p and the structure of U2 small nuclear RNA. Proc Natl Acad Sci U S A. 2003;100:13857-62.

26. Kistler AL, Guthrie C. Deletion of MUD2, the yeast homolog of U2AF65, can bypass the requirement for sub2, an essential spliceosomal ATPase. Genes Dev. 2001;15:42-9.

27. Raghunathan PL, Guthrie C. RNA unwinding in U4/U6 snRNPs requires ATP hydrolysis and the DEIH-box splicing factor Brr2. Curr Biol. 1998;8:847-55.

28. Laggerbauer B, Achsel T, Lührmann R. The human U5-200kD DEXH-box protein unwinds U4/U6 RNA duplices in vitro. Proc Natl Acad Sci U S A. 1998;95:4188-92 
29. Staley JP, Guthrie C. An RNA switch at the $5^{\prime}$ splice site requires ATP and the DEAD box protein Prp28p. Mol Cell. 1999;3:55-64.

30. Lin RJ, Lustig AJ, Abelson J. Splicing of yeast nuclear pre-mRNA in vitro requires a functional 405 spliceosome and several extrinsic factors. Genes Dev. 1987;1:7-18.

31. Kim SH, Lin RJ. Spliceosome activation by PRP2 ATPase prior to the first transesterification reaction of pre-mRNA splicing. Mol Cell Biol. 1996;16:6810-9.

32. Schwer B, Guthrie C. PRP16 is an RNA-dependent ATPase that interacts transiently with the spliceosome. Nature. 1991:349:494-9.

33. Company M, Arenas J, Abelson J. Requirement of the RNA helicase-like protein PRP22 for release of messenger RNA from spliceosomes. Nature. 1991;349:487-93.

34. Arenas JE, Abelson JN. Prp43: An RNA helicase-like factor involved in spliceosome disassembly. Proc Natl Acad Sci U S A. 1997;94:11798-802.

35. Tsai RT, Fu RH, Yeh FL, Tseng CK, Lin YC, Huang YH, et al. Spliceosome disassembly catalyzed by Prp43 and its associated components Ntr1 and Ntr2. Genes Dev. 2005;19:2991-3003.

36. Lardelli RM, Thompson JX, Yates 3rd JR, Stevens SW. Release of SF3 from the intron branchpoint activates the first step of pre-mRNA splicing. RNA. 2010;16:516-28.

37. Tseng CK, Liu HL, Cheng SC. DEAH-box ATPase Prp16 has dual roles in remodeling of the spliceosome in catalytic steps. RNA. 2011;17:145-54.

38. Schwer B, Gross CH. Prp22, a DExH-box RNA helicase, plays two distinct roles in yeast pre-mRNA splicing. EMBO J. 1998;17:2086-94.

39. Xu YZ, Query CC. Competition between the ATPase Prp5 and branch region-U2 snRNA pairing modulates the fidelity of spliceosome assembly. Mol Cell. 2007;28:838-49.

40. Liang WW, Cheng SC. A novel mechanism for Prp5 function in prespliceosome formation and proofreading the branch site sequence. Genes Dev. 2015;29:81-93.

41. Mayas RM, Maita H, Staley JP. Exon ligation is proofread by the DExD/H-box ATPase Prp22p. Nat Struct Mol Biol. 2006;13:482-90.

42. Yang F, Wang XY, Zhang ZM, Pu J, Fan YJ, Zhou J, et al. Splicing proofreading at $5^{\prime}$ splice sites by ATPase Prp28p. Nucleic Acids Res. 2013:41:4660-70

43. Koodathingal P, Novak T, Piccirilli JA, Staley JP. The DEAH box ATPases Prp16 and Prp43 cooperate to proofread 5' splice site cleavage during pre-mRNA splicing. Mol Cell. 2010;39:385-95.

44. Burgess SM, Guthrie C. A mechanism to enhance mRNA splicing fidelity: the RNA-dependent ATPase Prp16 governs usage of a discard pathway for aberrant lariat intermediates. Cell. 1993;73:1377-91.

45. Séraphin B, Rosbash M. Identification of functional U1 snRNA-pre-mRNA complexes committed to spliceosome assembly and splicing. Cell. 1989:59:349-58

46. Query CC, McCaw PS, Sharp PA. A minimal spliceosomal complex A recognizes the branch site and polypyrimidine tract. Mol Cell Biol. 1997;17:2944-53.

47. Huang YH, Chung CS, Kao DI, Kao TC, Cheng SC. Sad1 Counteracts Brr2Mediated Dissociation of U4/U6.U5 in Tri-snRNP Homeostasis. Mol Cell Biol. 2014;34:210-20.

48. Sharp PA. On the origin of RNA splicing and introns. Cell. 1985;42:397-400.

49. Cech TR. The generality of self-splicing RNA: relationship to nuclear mRNA splicing. Cell. 1986;44:207-10.

50. Tarn WY, Hsu CH, Huang KT, Chen HR, Kao HY, Lee KR, et al. Functional association of essential splicing factor(s) with PRP19 in a protein complex. EMBO J. 1994;13:2421-31.

51. Chan SP, Kao DI, Tsai WY, Cheng SC. The Prp19p-associated complex in spliceosome activation. Science. 2003:302:279-82.

52. Chan SP, Cheng SC. The Prp19-associated complex is required for specifying interactions of U5 and U6 with pre-mRNA during spliceosome activation. J Biol Chem. 2005;280:31190-9.

53. Chen HC, Cheng SC. Functional roles of protein splicing factors. Biosci Rep. 2012;32:345-59.

54. Abovich N, Liao XC, Rosbash M. The yeast MUD2 protein: an interaction with PRP11 defines a bridge between commitment complexes and U2 snRNP addition. Genes Dev. 1994;8:843-54.

55. Abovich $\mathrm{N}$, Rosbash M. Cross-intron bridging interactions in the yeast commitment complex are conserved in mammals. Cell. 1997:89:403-12.
56. Berglund JA, Chua K, Abovich N, Reed R, Rosbash M. The splicing factor BBP interacts specifically with the pre-mRNA branchpoint sequence UACUAAC. Cell. 1997:89:781-7.

57. Chang J, Schwer B, Shuman S. Structure-function analysis and genetic interactions of the yeast branchpoint binding protein Msl5. Nucleic Acids Res. 2012;40:4539-52.

58. Shen $H$, Zheng X, Shen J, Zhang L, Zhao R, Green MR. Distinct activities of the DExD/H-box splicing factor hUAP56 facilitate stepwise assembly of the spliceosome. Genes Dev. 2008;22:1796-803.

59. Wang Q, Zhang L, Lynn B, Rymond BC. A BBP-Mud2p heterodimer mediates branchpoint recognition and influences splicing substrate abundance in budding yeast. Nucleic Acids Res. 2008;36:2787-98.

60. Zhang M, Green MR. Identification and characterization of yUAP/Sub2p, a yeast homolog of the essential human pre-mRNA splicing factor hUAP56. Genes Dev. 2001;15:30-5.

61. Jensen TH, Boulay J, Rosbash M, Libri D. The DECD box putative ATPase Sub2p is an early mRNA export factor. Curr Biol. 2001;11:1711-5.

62. Strasser $K$, Hurt E. Splicing factor Sub2p is required for nuclear mRNA export through its interaction with Yra1p. Nature. 2001;413:648-52.

63. Luo ML, Zhou Z, Magni K, Christoforides C, Rappsilber J, Mann M, et al. Pre-mRNA splicing and mRNA export linked by direct interactions between UAP56 and Aly. Nature. 2001;413:644-7.

64. O'Day CL, Dalbadie-McFarland G, Abelson J. The Saccharomyces cerevisiae Prp5 protein has RNA-dependent ATPase activity with specificity for U2 small nuclear RNA. J Biol Chem. 1996:271:33261-7.

65. Ruby SW, Chang TH, Abelson J. Four yeast spliceosomal proteins (PRP5, PRP9, PRP11, and PRP21) interact to promote U2 snRNP binding to pre-mRNA. Genes Dev. 1993;7:1909-25.

66. Wells SE, Ares Jr M. Interactions between highly conserved U2 small nuclear RNA structures and Prp5p, Prp9p, Prp11p, and Prp21p proteins are required to ensure integrity of the U2 small nuclear ribonucleoprotein in Saccharomyces cerevisiae. Mol Cell Biol. 1994;14:6337-49.

67. Will CL, Urlaub H, Achsel T, Gentzel M, Wilm M, Luhrmann R. Characterization of novel SF3b and 17S U2 snRNP proteins, including a human Prp5p homologue and an SF3b DEAD-box protein. EMBO J. 2002;21:4978-88

68. Xu YZ, Newnham CM, Kameoka S, Huang T, Konarska MM, Query CC. Prp5 bridges U1 and U2 snRNPs and enables stable U2 snRNP association with intron RNA. EMBO J. 2004;23:376-85.

69. Chen JY, Stands L, Staley JP, Jackups Jr RR, Latus LJ, Chang TH. Specific alterations of U1-C protein or U1 small nuclear RNA can eliminate the requirement of Prp28p, an essential DEAD box splicing factor. Mol Cell. 2001;7:227-32.

70. Hage R, Tung L, Du H, Stands L, Rosbash M, Chang TH. A targeted bypass screen identifies Ynl187p, Prp42p, Snu71p, and Cbp80p for stable U1 snRNP/Pre-mRNA interaction. Mol Cell Biol. 2009;29:3941-52.

71. Mathew R, Hartmuth K, Möhlmann S, Urlaub H, Ficner R, Lührmann R. Phosphorylation of human PRP28 by SRPK2 is required for integration of the U4/U6-U5 tri-snRNP into the spliceosome. Nat Struct Mol Biol. 2008;15:435-43.

72. Kim DH, Rossi JJ. The first ATPase domain of the yeast 246-kDa protein is required for in vivo unwinding of the U4/U6 duplex. RNA. 1999;5:959-71.

73. Maeder C, Kutach AK, Guthrie C. ATP-dependent unwinding of U4/U6 snRNAs by the Brr2 helicase requires the $C$ terminus of Prp8. Nat Struct Mol Biol. 2009;16:42-8.

74. Mozaffari-Jovin S, Santos KF, Hsiao HH, Will CL, Urlaub H, Wahl MC, et al. The Prp8 RNase H-like domain inhibits Brr2-mediated U4/U6 snRNA unwinding by blocking Brr2 loading onto the U4 snRNA. Genes Dev. 2012;26:2422-34

75. Hahn D, Kudla G, Tollervey D, Beggs JD. Brr2p-mediated conformational rearrangements in the spliceosome during activation and substrate repositioning. Genes Dev. 2012;26:2408-21.

76. Mozaffari-Jovin S, Wandersleben T, Santos KF, Will CL, Luhrmann R, Wahl MC. Inhibition of RNA helicase Brr2 by the C-terminal tail of the spliceosomal protein Prp8. Science. 2013;341:80-4.

77. Noble SM, Guthrie C. Identification of novel genes required for yeast pre-mRNA splicing by means of cold-sensitive mutations. Genetics. 1996;143:67-80.

78. van Nues RW, Beggs JD. Functional contacts with a range of splicing proteins suggest a central role for Brr $2 p$ in the dynamic control of the order of events in spliceosomes of Saccharomyces cerevisiae. Genetics. 2001;157:1451-67. 
79. Zhang L, Xu T, Maeder C, Bud LO, Shanks J, Nix J, et al. Structural evidence for consecutive Hel308-like modules in the spliceosomal ATPase Brr2. Nat Struct Mol Biol. 2009;16:731-9.

80. Tsai RT, Tseng CK, Lee PJ, Chen HC, Fu RH, Chang KJ, et al. Dynamic interactions of Ntr1-Ntr2 with Prp43 and with U5 govern the recruitment of Prp43 to mediate spliceosome disassembly. Mol Cell Biol. 2007; 27:8027-37

81. Liu HL, Cheng SC. The interaction of Prp2 with a defined region of the intron is required for the first splicing reaction. Mol Cell Biol. 2012;32:5056-66.

82. Chen HC, Tseng CK, Tsai RT, Chung CS, Cheng SC. Link of NTR-mediated spliceosome disassembly with DEAH-box ATPases Prp2, Prp16, and Prp22. Mol Cell Biol. 2013;33:514-25.

83. Cordin O, Hahn D, Alexander R, Gautam A, Saveanu C, Barrass JD, et al Brr2p carboxy-terminal Sec63 domain modulates Prp16 splicing RNA helicase. Nucleic Acids Res. 2014;42:13897-910.

84. Small EC, Leggett SR, Winans AA, Staley JP. The EF-G-like GTPase Snu114p regulates spliceosome dynamics mediated by Brr2p, a DExD/H box ATPase. Mol Cell. 2006;23:389-99.

85. Fourmann JB, Schmitzova J, Christian H, Urlaub H, Ficner R, Boon KL, et al. Dissection of the factor requirements for spliceosome disassembly and the elucidation of its dissociation products using a purified splicing system. Genes Dev. 2013;27:413-28.

86. Warkocki Z, Odenwalder P, Schmitzova J, Platzmann F, Stark H, Urlaub H, et al. Reconstitution of both steps of Saccharomyces cerevisiae splicing with purified spliceosomal components. Nat Struct Mol Biol. 2009;16:1237-43.

87. Roy J, Kim K, Maddock JR, Anthony JG, Woolford Jr JL. The final stages of spliceosome maturation require Spp2p that can interact with the DEAH box protein Prp2p and promote step 1 of splicing. RNA. 1995;1:375-90.

88. Silverman EJ, Maeda A, Wei J, Smith P, Beggs JD, Lin RJ. Interaction between a G-patch protein and a spliceosomal DEXD/H-box ATPase that is critical for splicing. Mol Cell Biol. 2004;24:10101-10

89. Warkocki Z, Schneider C, Mozaffari-Jovin S, Schmitzova J, Hobartner C, Fabrizio P, et al. The G-patch protein Spp2 couples the spliceosome-stimulated ATPase activity of the DEAH-box protein Prp2 to catalytic activation of the spliceosome. Genes Dev. 2015;29:94-107.

90. Gozani O, Potashkin J, Reed R. A potential role for U2AF-SAP 155 interactions in recruiting U2 snRNP to the branch site. Mol Cell Biol. 1998;18:4752-60.

91. McPheeters DS, Muhlenkamp P. Spatial organization of protein-RNA interactions in the branch site-3' splice site region during pre-mRNA splicing in yeast. Mol Cell Biol. 2003;23:4174-86.

92. Yeh TC, Liu HL, Chung CS, Wu NY, Liu YC, Cheng SC. Splicing factor Cwc22 is required for the function of Prp2 and for the spliceosome to escape from a futile pathway. Mol Cell Biol. 2011;31:43-53.

93. Ohrt T, Prior M, Dannenberg J, Odenwalder P, Dybkov O, Rasche N, et al. Prp2-mediated protein rearrangements at the catalytic core of the spliceosome as revealed by dcFCCS. RNA. 2012;18:1244-56.

94. Teigelkamp S, McGarvey M, Plumpton M, Beggs JD. The splicing factor PRP2, a putative RNA helicase, interacts directly with pre-mRNA. EMBO J. 1994;13:888-97.

95. Horowitz DS, Abelson J. Stages in the second reaction of pre-mRNA splicing the final step is ATP independent. Genes Dev. 1993;7:320-9.

96. Ansari A, Schwer B. SLU7 and a novel activity, SSF1, act during the PRP16-dependent step of yeast pre-mRNA splicing. EMBO J. 1995;14:4001-9.

97. Ohrt T, Odenwalder P, Dannenberg J, Prior M, Warkocki Z, Schmitzova J, et al. Molecular dissection of step 2 catalysis of yeast pre-mRNA splicing investigated in a purified system. RNA. 2013;19:902-15.

98. Burgess S, Couto JR, Guthrie C. A putative ATP binding protein influences the fidelity of branchpoint recognition in yeast splicing. Cell. 1990;60:705-17.

99. Couto JR, Tamm J, Parker R, Guthrie C. A trans-acting suppressor restores splicing of a yeast intron with a branch point mutation. Genes Dev. 1987;1:445-55

100. Schwer B, Guthrie C. A conformational rearrangement in the spliceosome is dependent on PRP16 and ATP hydrolysis. EMBO J. 1992;11:5033-9.

101. McPheeters DS, Schwer B, Muhlenkamp P. Interaction of the yeast DExH-box RNA helicase prp22p with the $3^{\prime}$ splice site during the second step of nuclear pre-mRNA splicing. Nucleic Acids Res. 2000;28:1313-21.

102. Mefford MA, Staley JP. Evidence that U2/U6 helix I promotes both catalytic steps of pre-mRNA splicing and rearranges in between these steps. RNA. 2009;15:1386-97.
103. Hilliker AK, Mefford MA, Staley JP. U2 toggles iteratively between the stem Ila and stem IIc conformations to promote pre-mRNA splicing. Genes Dev. 2007;21:821-34.

104. Perriman RJ, Ares Jr M. Rearrangement of competing U2 RNA helices within the spliceosome promotes multiple steps in splicing. Genes Dev. 2007;21:811-20.

105. Wang Y, Wagner JD, Guthrie C. The DEAH-box splicing factor Prp16 unwinds RNA duplexes in vitro. Curr Biol. 1998;8:441-51.

106. Hogg R, de Almeida RA, Ruckshanthi JPD, O'Keefe RT. Remodeling of U2-U6 snRNA helix I during pre-mRNA splicing by Prp16 and the NineTeen Complex protein Cwc2. Nucl Acids Res. 2014;42:8008-23.

107. Villa T, Guthrie C. The Isy1p component of the NineTeen complex interacts with the ATPase Prp16p to regulate the fidelity of pre-mRNA splicing. Genes Dev. 2005;19:1894-904.

108. Query CC, Konarska MM. Suppression of multiple substrate mutations by spliceosomal prp8 alleles suggests functional correlations with ribosomal ambiguity mutants. Mol Cell. 2004;14:343-54

109. Madhani HD, Guthrie C. Genetic interactions between the yeast RNA helicase homolog Prp16 and spliceosomal snRNAs identify candidate ligands for the Prp16 RNA-dependent ATPase. Genetics. 1994;137:677-87.

110. Schwer B. A conformational rearrangement in the spliceosome sets the stage for Prp22-dependent mRNA release. Mol Cell. 2008;30:743-54.

111. Wagner JD, Jankowsky E, Company M, Pyle AM, Abelson JN. The DEAH-box protein PRP22 is an ATPase that mediates ATP-dependent mRNA release from the spliceosome and unwinds RNA duplexes. EMBO J. 1998;17:2926-37.

112. Schwer B, Meszaros T. RNA helicase dynamics in pre-mRNA splicing. EMBO J. 2000;19:6582-91

113. Schneider S, Campodonico E, Schwer B. Motifs IV and V in the DEAH box splicing factor Prp22 are important for RNA unwinding, and helicase-defective Prp22 mutants are suppressed by Prp8. J Biol Chem. 2004;279:8617-26.

114. Aronova A, Bačíková D, Crotti LB, Horowitz DS, Schwer B. Functional interactions between Prp8, Prp18, Slu7, and U5 snRNA during the second step of pre-mRNA splicing. RNA. 2007;13:1437-44.

115. Martin A, Schneider S, Schwer B. Prp43 is an essential RNA-dependent ATPase required for release of lariat-intron from the spliceosome. J Biol Chem. 2002;277:17743-50.

116. Mayas RM, Maita H, Semlow DR, Staley JP. Spliceosome discards intermediates via the DEAH box ATPase Prp43p. Proc Natl Acad Sci U S A. 2010;107:10020-5.

117. Boon KL, Auchynnikava T, Edwalds-Gilbert G, Barrass JD, Droop AP, Dez C, et al. Yeast ntr1/spp382 mediates prp43 function in postspliceosomes. Mol Cell Biol. 2006:26:6016-23.

118. Pandit S, Lynn B, Rymond BC. Inhibition of a spliceosome turnover pathway suppresses splicing defects. Proc Natl Acad Sci U S A. 2006;103:13700-5.

119. Tanaka N, Aronova A, Schwer B. Ntr1 activates the Prp43 helicase to trigger release of lariat-intron from the spliceosome. Genes Dev. 2007;21:2312-25.

120. Tanaka N, Schwer B. Mutations in PRP43 that uncouple RNA-dependent NTPase activity and pre-mRNA splicing function. Biochemistry. 2006;45:6510-21

121. Burgess SM, Guthrie C. Beat the clock: paradigms for NTPases in the maintenance of biological fidelity. Trends Biochem Sci. 1993;18:381-4.

122. Wlodaver AM, Staley JP. The DExD/H-box ATPase Prp2p destabilizes and proofreads the catalytic RNA core of the spliceosome. RNA. 2014;20:282-94.

123. Horowitz DS. The splice is right: guarantors of fidelity in pre-mRNA splicing. RNA. 2011;17:551-4.

\section{Submit your next manuscript to BioMed Central and take full advantage of:}

- Convenient online submission

- Thorough peer review

- No space constraints or color figure charges

- Immediate publication on acceptance

- Inclusion in PubMed, CAS, Scopus and Google Scholar

- Research which is freely available for redistribution 